\title{
The Unbearable Lightness of Being Retired
}

\author{
Michelle Pannor Silver \\ University of Toronto Scarborough, Department of Sociology and the Interdisciplinary Centre for \\ Health and Society
}

\begin{abstract}
RÉSUMÉ
Dans cette étude qualitative, j'ai utilisé une approche fondée sur la gérontologie narrative pour examiner les perceptions liées à la retraite dans un groupe de 26 hommes et femmes qui ont pris leur retraite après un mandat de chef de la direction. Le guide d'entrevue a pris en compte la perspective du parcours de vie. Trois thèmes clés ont émergé : 1) l'importance de la productivité et du réseautage, alors que les participants gravissaient les échelons de l'entreprise ; 2) le sentiment d'avoir une date " meilleur avant » et d'avoir cédé aux pressions de la société en faveur de la retraite ; et 3) l'impression troublante de se sentir insignifiant à la retraite tout en ayant le désir de poursuivre l'épanouissement personnel en continuant à travailler contre rémunération. Après une carrière marquée par des réalisations pionnières, les participants ont éprouvé un sentiment insoutenable de légèreté lors de l'abandon des responsabilités professionnelles. Ces résultats mettent en lumière l'importance de la perspective de parcours de vie pour examiner la retraite à la fois comme une expérience personnelle et un phénomène social. Les résultats contribuent également à la compréhension théorique du vieillissement productif en illustrant comment les idées préconçues sur la productivité contrastent avec les aspirations associées à une retraite remplie de loisirs, d'une manière qui pourrait réduire les contributions à l'emploi de certaines personnes.
\end{abstract}

\begin{abstract}
In this qualitative study, I followed an approach to examine perceptions about retirement, using an interview guide informed by the life course perspective, among 26 men and women who had retired from positions as chief executive officers. Three key themes emerged: (1) the importance of productivity and networking as participants rose up the corporate ladder; (2) the sense of having a "best before" date and experiencing societal pressures to retire; and (3) struggles with feeling insignificant in retirement while desiring personal fulfillment through continued engagement in paid work. These findings shed light on the value of using a life course perspective to examine retirement as both a personal experience and as a social phenomenon. Findings also contribute to theoretical understandings of productive aging by illustrating how preconceptions about productivity contrast with ideations of a leisure-filled retirement in ways that can foreshorten the employment contributions of some individuals.
\end{abstract}

Manuscript received: / manuscrit reçu : 19/09/17

Manuscript accepted: / manuscrit accepté : 07/07/18

Mots-clés : vieillissement, retraite, vieillissement productif, recherche qualitative

Keywords: aging, retirement, productive aging, qualitative research

La correspondance et les demandes de tirés-à-part doivent être adressées à : / Correspondence and requests for offprints should be sent to:

Michelle Pannor Silver, Ph.D.

Assistant Professor

Department of Sociology, Interdisciplinary Centre for Health and Society

University of Toronto Scarborough

1265 Military Trail

Toronto, ON M1C1A4

(michelle.silver@utoronto.ca)

\section{Introduction}

Since the oldest baby boomers turned 65 in 2011, approximately 10,000 people in the United States alone cross over the threshold of traditional retirement age every day (Cohn \& Taylor, 2010). Today, nearly
15 per cent of the population in North America and 20 per cent in countries like Japan, Germany, and Italy are older than 65 (World Bank Group, 2016). In Canada, the proportion of people aged 65 and older now exceeds the proportion of children under 15 years old (Statistics 
Canada, 2017a). The average Canadian worker retires at age 66 (Carrière \& Galarneau, 2012), while life expectancy is approximately 82 years (Statistics Canada, $2017 b)$. This gap between average retirement age and life expectancy necessitates more nuanced examinations of retirement experiences. The purpose of this narrative study was to examine "productive aging" within the context of the retirement experiences of men and women who had worked as chief executive officers (CEOs).

More than two decades ago, cultural norms associated with the rituals of retirement ceremonies were questioned (Savishinsky, 1995). Since then, researchers have questioned the viability of the term retirement (McDonald \& Donahue, 2011) and reworked the concept to create characterizations of specific statuses that can emerge in retirement (Hershenson, 2016). Given that the baby boomers have redefined social norms at each stage of their lives, it is no wonder that as they enter the realms of traditional retirement age, the meaning, timing, and purpose of retirement are undergoing significant shifts. Retirement was originally established in the late 19th century and instituted in the mid-20th century after the Second World War throughout North America and Europe as an agegraded exit from full-time employment to address concerns regarding later-life poverty (Hardy, 2011; Sass, 2006). But as life expectancy increased over the past century, understandings of retirement have moved away from associations with poverty, decline, and disengagement (Ekerdt \& DeViney, 1990; Sargeant, 2016).

Retirement has come to be understood as an actively constructed lifestyle option (Higgs \& Gilleard, 2006) that can create outsized expectations for later life (Ekerdt, 2004). Frameworks such as the "third age" depict retirement as a time after the adult career stage when an individual can create a lifestyle that is not career-dominated and also not isolated from the rest of society (Gilleard \& Higgs, 2002; Laslett, 1989). Contemporary understandings of retirement are complicated by media portrayals and advertisements that depict handsome and wealthy retirees playing golf or engaging in other leisure activities while air-brushing over challenges associated with aging (Katz, 2005; Katz \& Calasanti, 2014). Important concerns have been raised about societal obsessions with aging activity (Ekerdt, 1986; Katz, 2000; Marshall \& Katz, 2002), anti-aging (Katz, 2001; 2005), and successful or productive aging (e.g., Baltes \& Carstensen, 1996; Bülow \& Söderqvist, 2014; Foster \& Walker, 2014), thus calling into question all that is embedded in the construct of retirement.

The current cohort of individuals approaching the "third age" or traditional retirement age is distinct from their predecessors in many ways, including the fact that this cohort includes unprecedented numbers of women with work experiences in the paid labour force. Previous research acknowledges the need to examine potential differences in women's retirement experiences for a range of reasons including the distinct societal expectations regarding caregiving responsibilities, economic insecurity, and health concerns for women in retirement (Price \& Nesteruk, 2010; Szinovacz, 2003). This supports the need for research that includes women in studies of retirement and impugns early conceptualizations of retirement that failed to include women's experiences (Moen \& Roehling, 2005; Price, 2000, 2003).

\section{Theoretical Framework}

Within the gerontology literature, "productive aging" has been employed to conceptualize retirement in ways that emphasize the benefits of engagement in activities that make economic contributions to society in later stages of the life course (Bass, Caro, \& Chen, 1993; Gonzales, Matz-Costa, \& Morrow-Howell, 2015). This framework focuses on how productive activity in retirement - such as paid work, volunteering, or caregiving - is favourable for individuals and for society (Morrow-Howell \& Wang, 2013). Productive aging is a sharp contrast to earlier conceptualizations of retirement that underscored decline and isolation (Butler \& Gleason, 1985; Morrow-Howell, Hinterlong, \& Sherraden, 2001; O'Reilly \& Caro, 1995) and is also a contrast to cultural depictions of the "golden years" that represent retirement as a time to enjoy life without the burdens of work (Hicks \& Siedlecki, 2017). Productive aging has been criticized for imposing negative judgements on older adults who fail to engage in economically productive activity for a variety of reasons including declining health or caregiving obligations (Bülow \& Söderqvist, 2014; Dillaway \& Byrnes, 2009; Holstein, 1993; Martinson \& Halpern, 2011).

A rich literature has focused on the social processes that contribute to our understanding of retirement (Barnes \& Parry, 2004; Osborne, 2009; Vickerstaff \& Cox, 2005), yet a challenge remains for working men and women in leadership positions who transition to retirement within societies that value productivity but also endorse a leisure-filled retirement lifestyle. In this study, I examined "productive aging" within the context of the retirement experiences of a set of CEOs, men and women whose working lives focused on productivity.

\section{Method}

Study Design

For this qualitative study, I conducted 26 in-person, semi-structured interviews following an approach 
guided by narrative gerontology. As a framework to guide qualitative research, narrative gerontology encourages the use of interview methods to study later life transitions, upholding the notion that narratives are shaped by cultural expectations and social norms (de Medeiros, 2013; Kenyon, Bohlmeijer, \& Randall, 2010; Kenyon, Clark, \& de Vries, 2001; Phoenix \& Smith, 2011). Narrative gerontology encourages the researcher to listen to people's stories, engage with them on multiple occasions, and discuss substantive issues directly with them. It assumes that the primary way humans make meaning of experiences, relationships, phenomena, and life transitions, such as retirement, is by sharing stories rather than discrete facts.

\section{Eligibility Criteria}

I applied the following criteria to establish eligibility for this study: men or women who had held the position of CEO of a hospital or health care organization and those who self-identified as being retired for at least four years. I decided on the requirement of being retired for at least four years in an effort to maximize the possibility that participants' retirement status was stable in light of research on bridge retirement and "unretirement" indicating that later-life employment status changes are not uncommon within the first few years of an initial transition to retirement (Beehr \& Bennett, 2015; Maestas, 2010).

I focused on CEOs because their situation presents a unique vantage point from which to examine a work identity that can be all-consuming (Obodaru, 2012). By definition, the $\mathrm{CEO}$ of a large enterprise is the highestranking corporate executive with the responsibility to oversee or delegate the oversight of numerous employees. Sonnenfeld's The Hero's Farewell (1991) demonstrated the range of departure styles that successful CEOs exhibit, revealing how ill-prepared CEOs tend to be for their own transition to retirement. In particular, CEOs of health care organizations face challenges because they are charged with managing complex organizations that must maintain the highest standards for safety and reliability in order to minimize patient harm (Chassin \& Loeb, 2013); thus, their work is about more than generating profits. Health care CEOs must shoulder the burden of responsibility when medical errors take place, infections are spread, and other related incidents take place within hospitals (Klevens et al., 2007; Swayne, Duncan, \& Ginter, 2012).

\section{Recruitment Procedures}

To aid in participant recruitment, I established a set of contacts who were affiliated with organizations that created social networking opportunities for retired CEOs. These contacts helped me connect with retired individuals who had worked as a CEO in the health care sector by making announcements at events, through word-of-mouth, and by providing potential participants with information about the study and my contact information. Additional participants were recruited through snowball sampling, where I asked existing participants to pass on my contact information to eligible peers (Patton, 1990). I had a more difficult time recruiting women for this study, largely because fewer women rise to the rank of CEO; consequently, I used purposive recruitment through contacts as well as snowball sampling to recruit eligible women to the study.

\section{Interview Guide}

In keeping with traditional methods employed within narrative gerontology, my primary objective during the interviews was to hear each participant's story in a way that focused on their retirement experience while considering multiple aspects of their life experience. I used an interview guide that focused on participants' perceptions about work, aging, and retirement following a life course, theoretical perspective that emphasized participants' sense of developmental timing, historical time and place, personal agency, and linked lives (Giele \& Elder, 1998). The life course perspective has often been applied in research on aging and later life transitions to suggest that people process normative expectations of age in the context of their own circumstances (Elder, 1994; Marshall \& Mueller, 2003).

Applying this framework, I began each interview by asking participants to describe their entry into the paid workforce and then to tell me about their career trajectory, highlighting professional and personal transitions that took place during their lives (such as changes in job titles, family composition, residential relocations, and health-related incidents). Following this, I focused on participants' retirement experiences, asking questions such as "What are your perceptions of retirement?", "Have your perceptions of retirement changed now that you are retired?", and "How have your perceptions changed?" I conducted all of the in-person interviews in English. Each interview lasted approximately an hour and a half (range: 61-193 minutes). I took notes during each interview, and all interviews were audio-recorded and transcribed verbatim. I received ethical approval for this study from the University of Toronto Research Ethics Board. To protect the confidentiality of all participants, I have used pseudonyms for the participants' names and changed clearly identifying characteristics.

\section{Data Analysis}

My analytic process followed a method that has been invoked in narrative gerontology and by story analysts 
from a range of disciplines. In the initial stages of my analytic process, I listened to the audio recordings from each interview and repeatedly read over my notes and each transcript. After familiarizing myself with the interviews, I applied analytic techniques relevant to narrative gerontology to examine participants' perceptions of retirement in relation to their work and later career transitions. In the first stage of my analysis, I examined the transcripts focusing on major transition points in each participant's life. In the next stage of analysis, I used an inductive and iterative coding process to develop thematic interpretations of participants' work and retirement experiences (Miles \& Huberman, 1994). I kept an audit trail to record decisions I made in the development of key themes. In addition, I met with three small groups of participants to corroborate my themes and ensure that these resonated with participants (Lincoln \& Guba, 1985).

\section{Sample}

In total, seven of the 26 CEOs I interviewed were women. Participants held the position of CEO for a health care organization in one of nine countries: Australia, Canada, England, Germany, Ireland, Kuwait, Qatar, United States, and United Arab Emirates. The majority of participants resided in Canada for the entirety of their career. The average age of participants at the time of their interview was 68 years old, and, on average, participants described six career transitions that involved a change in their job title prior to retiring. The majority of participants were married and Caucasian; one quarter of the sample were visible minorities. Over half the sample had children, and just under half of the sample had grandchildren.

\section{Findings}

As participants described their ambitious work trajectories and transitions to retirement, three key themes emerged. First, their steep ascent to the top of the corporate ladder involved a continuous focus on work productivity and networking. Next, participants conveyed feeling as though they had a "best before" or "expired by" date that obligated them to retire despite their personal abilities and interest in continuing to work. Finally, in their retirement, participants discussed their struggles with feeling insignificant, until many found fulfillment through re-engagement in paid work.

\section{Importance of Productivity and Networking}

Participants' ascent to becoming a CEO had been a dynamic upward progression. Participants considered themselves productive if they were constantly changing job titles, thinking about their next career move, and consistently planning for the future. Beginning from their early career stages, multiple participants mentioned that they would accept a job with their next job already in mind. Most participants described themselves as being highly productive, good at seizing career opportunities, and capable of readily adjusting to different jobs.

One participant, who had 15 career transitions at seven different organizations in three different countries, described his rise to becoming a CEO as a calculated one. He explained that moving up the corporate ladder was his main driving force from an early point in his life:

\section{I began to think about the possibility of being a CEO almost in terms of a game. Could I move through the system in some reasonable point in time and get to the top of the heap? [John, 68 years old, retired 4 years]}

Work took precedence over other potential obligations or spheres of all participants' lives. It was not uncommon for participants to explain that almost all of their memories of adulthood had to do with work and work-related functions. Several participants lamented their choices when it came to balancing work and life outside of work. Not all were regretful, but many shared a sense that rising to the top required some sacrifices. Reflecting back on his career, another participant explained:
When I look back, I think I could have been a better father, better husband ... When I look back, I think it's true, there were times I considered my career more important than anything else in my life. [Ralph, 62 years old, retired 4 years]

Participants described the importance of social networking as they moved up through the ranks of hospital administration, emphasizing its role in helping them achieve their career ambitions. For example, a participant described the importance of personal relationships in his quest to become a CEO of a large hospital as he explained:
There's an enormous amount of luck involved. There's an enormous amount of political capital that's used up, or used in order to become a CEO. Relationships matter hugely. Relationships with head hunters matter hugely. Networks matter hugely. [Robert, 61 years old, retired 6 years]

Close social networks developed through work often also served as distractions from participants' private lives, and, for some, their connections through work led to extramarital affairs. More than one participant described how work served as a threat to their marriage because it created opportunities to meet people and was an excuse to be away from home. For example, 
after describing years of enduring a high-stress work environment, one participant discussed a relationship he established with someone at work while being married:

I did not have a good work-life balance. It was mostly because I committed myself to work. I don't regret [the affair]. It was all during a very stressful time at work. But it was my fault and a key factor in splitting up with my first wife. [Philip, 71 years old, retired 6 years]

It was clear that for many participants, work took precedence over other obligations or aspects of their lives. Throughout the earlier parts of their careers, work had been a source of gratification and a way to receive positive feedback that might have been absent or lacking in their home life. In discussing their own engagement in an extramarital affair with a co-worker, two participants used variations of the term "flawed" to describe the ways they allowed themselves to prioritize their work and work relationships. In reflecting on regrets about their work-life balance, participants revealed themselves to be individuals capable of both experiencing and inflicting pain. Several acknowledged a sense of personal fallibility, if not remorse, for having placed such intense focus on their work ambitions and work relationships.

Some of the women commented on the fact that having children was "not in the cards" because it would not have been possible to maintain a private life that was entirely distinct from work. In reflecting on their choices from the vantage point of retirement, each of the women commented on how unique it was to be a female CEO of a health care organization. In contrast, only a handful of the men raised comments about gender discrepancies in their line of work, and, when they did, it was to mention that health care tended to be female-dominated among nurses at the front lines and male-dominated at the management level. The women noted that their rise to becoming a CEO required demonstrating higher levels of productivity and greater personal sacrifice compared with men they knew in comparable positions. For example, one participant said:

I had to show that I was twice as good as any man they could have hired ... I worked very hard and now I see that meant not taking time to develop interests that might be meaningful to me now in retirement. [Janice, 62 years old, retired 5 years]

Each of the women I interviewed described her rise to becoming CEO in remarkably similar terms to the men, particularly when it came to discussing their dedication to their work. Overall, participants depicted themselves as highly productive and took pride in the fact that their work had been all-consuming. Being the
CEO was described as the pinnacle of their career and, by most participants, as the highlight of their lives. One participant summarized his own experience as well as that of his large network of fellow retired CEOs as follows:

I think that in some ways the work demands sort of allowed me to throw myself into work and avoid dealing with all sorts of things. I had to work. It's a well-known trick. [Ken, 68 years old, retired 4 years]

Like other participants, Ken acknowledged his own use of work as an excuse for avoiding family responsibilities. As he reflected on his willingness to engage in the "well-known trick" of throwing himself into his work, I observed an acknowledgement of his own shortcomings and at the same time, a revelation that work had been a way to achieve the gratification that he yearned for but could not attain from other realms of his life. Some used the trick of focusing on work to the near exclusion of anything else because working is essential, whereas the degree to which other aspects of life can be considered essential is more subjective. Societal rules objectively imply that we must work in order to earn a living, whereas how and whether to experience devotion to family, friends, or a life outside of work is more subjective. The pursuit of productivity at work permitted some participants to evade other interests or to obfuscate demands from other realms of life.

\section{Having a "Best Before" Date}

In general, participants explained that a successful transition to retirement was epitomized by having a keen sense of when to leave. Several participants explained that they retired based on their age and that remaining in a leadership position in health care for too long could cause problems for the organization. Many held perceptions that health care thrives on vitality, "youth", and "innovation". Often renewal, defined as replacing older workers with younger ones, was seen as the key to having a strong organization. Like a carton of milk, the CEOs described having a "best before" or expiry date that was often imposed by boards of directors or work norms. In multiple ways, retirement was described as something that participants were expected to do before they got "too old". As one participant explained:

I knew I had to get out of there before they started looking at me as though I were too old for the job. [Mary, 58 years old, retired 4 years]

And another participant worried that staying on would mean stagnation for the organization:

I felt if I stayed any longer, you reach a certain age where no one wants to take a chance on you anyway, they think you're just going to retire. [Nandan, 61 years old, retired 4 years] 
Participants either felt direct pressure to retire or a latent expectation that they ought to step down from their reign of power before they advanced too far in years. Many participants explained that age was the impetus for their retirement and described a sense of obligation to retire despite their personal abilities and interest in continuing to work. None of the participants timed their retirement with a spouse or partner, and no one retired in order to provide caregiving or because of a health problem of their own. In describing his decision about when to retire, one participant discussed the challenges he faced when a predecessor delayed retirement:

\section{I had at least four jobs in my career where my predecessor stayed in the picture and it was a pain. Absolute pain, even if they were well inten- tioned. I vowed to myself I would never do that because I didn't enjoy having it done to me, and it isn't good for the vitality of the organization. [Martin, 70 years old, retired 5 years]}

Martin felt that failure to retire in a timely fashion was "a pain" for co-workers because staying on too long meant being out-of-date or out-of-touch. He described two specific examples of predecessors who made mistakes on the job and attributed these mistakes to their failure to recognize that it had been time to retire. Martin retired because he viewed himself as on the verge of being viewed as "too old" to be the CEO. He wanted to retire before anyone could blame him for staying on too long.

Others described more direct pressures to retire. One participant described a very difficult transition to retirement, one that had been forced and coincided with a cancer diagnosis. She explained that even though her cancer diagnosis was not terminal, it became a signal of her "aging" that was difficult to hide. She did not want to retire, but realized that she could not combat the concerns that others had about her ability to lead. She said:

\begin{abstract}
I don't know which was worse - the cancer or the loss of the career, you know? But they coincided, which made it worse. And then I thought, "well, I am old enough; I will retire. But then ... you know I had worked all my life ... I don't know how you get over [working], I started work when I was 14, you know? [Clare, 79 years old, retired 9 years]
\end{abstract}

If their decision to retire was not induced by pressures to step down, then participants explained that "retirement" was simply a euphemism used to publicly describe their termination in the press. More than one participant had been terminated for reasons they ascribed to ageist mismanagement. One participant was particularly surprised to learn about his "retirement" in the newspaper, only to be told later by the chair of his hospital's board of directors that his leadership skills were "out of date".

Several of the women I interviewed described a direct relationship between what they described as physical signs of their aging and their perceived abilities as a leader. Although some explained that looking older was helpful in gaining the respect of the teams they managed, others exerted great effort and personal agency to maintain a more youthful appearance in the years leading up to their retirement. Almost all of the women mentioned that they regularly used hair dye to cover gray hair, and many described feeling a need to maintain their physical appearance and connected it to their productivity as a CEO. One participant explained that she refused to dye her hair until she turned 60 and became a CEO, at which point she was advised by a friend who suggested that dying her hair would help her keep her job. Another participant mentioned that part of her regular preparation for board meetings was making sure that she got a chance to have her hair dyed because she worried about being perceived as old. Although the men did not mention specific concerns about their hair, they also emphasized the importance of maintaining their physical appearance. Some explained that regular exercise or working out with a personal trainer was an important aspect of their job and a component of what they needed to do in order to enhance their persona as an effective leader.

\section{Overcoming Insignificance}

Even though retirement brought on a shared sense of feeling a lesser burden on their shoulders, many participants were not content with enjoying their newfound freedom and expressed a lack of gravity associated with their current engagements, unless they had found another form of fulfilling, paid work. Participants worried about their legacies and expressed regrets about their current levels of productivity. This was a similar concern shared by several participants:

In my retirement, I feel a fear about becoming invisible and not contributing - I mean, I've got a strong work ethic and part of it is [fear] I'm not contributing. [Rebecca, 58 years old, retired 4 years]

Several participants shared a sense of ennui about being retired, which most often arose when they discussed their current daily routine. While serving as the CEO, participants had to shoulder the burden of responsibility for anything that went wrong within the hospital or health care organization they ran. Many acknowledged a light, "almost heavenly" feeling that they associated with no longer having to deal with stressful work issues they encountered as CEO, such as 
mistakes that had been made within the health care organizations they ran, disputes with labour unions, and lives that were lost at their hospitals. At the same time, participants experienced a lightness or sense of triviality that set in with retirement. For example, one participant explained:

\begin{abstract}
Being the CEO carries a particular weight, and I noticed it when I went from senior VP to CEO, because as a senior VP you can work long hours, but at the end of the day it's not yours. So, there's a weight to it that for me is heaven not carrying. It's hard to explain the weightlessness now, it's almost as if everything is trivial. [Joseph, 65 years old, retired 4 years]
\end{abstract}

Across the board, participants described a desire to be "fulfillment employed" or to re-engage in paid work that would provide them with the feeling that they were meaningfully contributing to society in their retirement. Fewer than half of the participants did some form of formal post-retirement employment, but many spoke of a deep-rooted desire to work again. Throughout their lives, work had given participants a sense of fulfillment in addition to an income. Now in retirement, working also represented a connection back to their core identity, access to social networks and additional income that could help them maintain their lifestyle. Several participants quickly re-entered the workforce once they retired because of the sense of grounding it brought them. One participant described the instant discomfort he felt with being outside the paid labour force when he retired and the sense of gratification that working afforded him:

Fifty-nine seconds after I retired, I took a position with [name of company] ... I'm not an extremely religious person but I felt like there was a bolt of lightning from some God ... I have complete freedom of my life, they pay relatively well for a parttime job, and I have a sense of grounding. [Salvador, 69 years old, retired 4 years]

Another participant explained:

I will always do some work, so I don't intend to never work. If I can, I'd like to stay engaged, and you know, partly it's stimulation and partly it's to continue to make some form of contribution. [Phyllis, 72 years old, retired 8 years]

Generally speaking, participants rejected the notion of retirement as the end of one's working life; instead, they suggested that being employed in fulfilling work was the first step in a successful retirement.

Many participants described retirement as a stage in life where they could rethink or redirect earlier ambitions and suggested that work offered the most direct way to find fulfillment. One participant characterized his initial stage of retirement as a time for "active recovery".
He explained that work was not just about being paid, although being paid reflected on his self-worth. He came to view work as something that was an important component of his retirement. For him, retirement was a time to reset and shift gears before working again:

I do spin classes and in the spin class they talk about active recovery. And they, after the intense part of bicycling, they say, we are in the "active stage of recovery. We want your heart rate to come down a little bit but it shouldn't come all the way down" ... So, I think actually this describes what I'm doing now ... My life is not nearly as demanding as it was when I was running [name of organization], but I'm not just watching TV all day either. It's somewhere in between. It's calibrated. [Craig, 67 years old, retired 4 years]

Even those who had an inchoate sense of what they would do next knew that it would involve returning to paid work in some form. One participant had held at least seven different career titles before he retired and had multiple phases of retirement. He summarized his retirement experience as follows:

I retired 15 years ago now and it's only very recently that I've decided to pull out of all of my associations. In my retirement, I've probably been as active as I had if I were working full time ... Now I'm, I'm going into phase two of retirement, sort of real retirement where at this point at least I'm not going to be running the meetings. And I'm not going to have any significant responsibilities. And I'm hoping my golf game improves ... But if somebody came to me tomorrow and offered me an interesting position, I would probably take it. But I wouldn't take five of them, which is sort of what I was doing previously. I would pick and choose very carefully for a little bit of activity. [Dean, 82 years old, retired 15 years]

Like many participants, Dean first "retired" at an age he deemed appropriate to step down from his position as CEO. His initial retirement included a generous compensation package and multiple opportunities to serve as a board member for various charitable organizations, but it also came with a sense of obligation to ratchet things down. Like Dean, participants shared a general willingness to remove themselves from being the "one in charge", but remained unable to recognize how their own acculturation and acquiescence to a work culture dominated by ageist assumptions about productivity drove them to their perceived state of insignificance.

\section{Discussion}

This study examined perceptions about retirement among a set of individuals whose work experiences took them to the top of the corporate ladder while 
fostering a near-exclusive focus on being productive. In describing their retirement transitions, participants described an abrupt shift from having been the one in charge to being someone who acquiesced to ageist norms while holding strong desires to continue to remain engaged in the paid workforce. These findings reinforce the notion that the true challenge for aging societies is not that the proportion of older adults is increasing, but instead how age is used to influence economic and social life (Carney \& Gray, 2015).

In response to the growing proportion of older adults around the world, policy-makers have engaged in various efforts to extend working lives (Powell \& Taylor, 2016; Vickerstaff, 2010). No participant in this study resided in a region or had worked in an organization that imposed mandatory retirement, yet they each retired from their career while possessing tremendous capabilities and interest in contributing to society by continuing to work. Findings suggest that policies linking retirement to a specific chronological age can foreshorten the contributions of individuals whose personal identity is attached to their sense of productivity and professional engagement.

Findings from this study also emphasize the utility of applying a life course perspective by examining retirement with an individual's full career in mind. Applying a life course perspective was also valuable to this study because it provided a framework that facilitated studying retirement as a social category while considering multiple aspects of the individualized human experience. Early in their lives, participants thrived on moving up in their careers and were willing to devote large amounts of time and emotional energy to their work. Some of their disappointment with retirement reflected beliefs set earlier in their lives that linked youth with productivity and unfilled expectations about retirement as an idealized time to enjoy the fruits of their labours.

This study contributes to research on productive aging (e.g., Butler \& Gleason, 1985) by illustrating the importance of cultural norms as a critical factor that influences role expectations about engagement in productive activities (Bass \& Caro, 2001). Participants' near exclusive focus on their work productivity left some regretful of the fact that they had not spent more time with family throughout their adulthood. Others recognized that they had let their work serve as an excuse to neglect the development of personal interests outside of work or to shirk family responsibilities. Each advanced in a career that rewarded a deep commitment, and then at a certain point, when each was expected to relinquish their position of power, they decided to, or had to, forgo the part of themselves that had been an important source of fulfillment.
In essence, these findings demonstrate that having a near constant focus on work productivity throughout adulthood can undermine the prospects of finding contentment in retirement.

Ekerdt's (1986) busy ethic conceptualizes multiple ways that productivity is praised by society and how retirement can be morally managed by providing a continuous framework for those who subscribe to the utility of keeping busy. Evidence suggests that age discrimination remains an issue of concern in the workplace (Bayl-Smith \& Griffin, 2014; McNamara, Pitt-Catsouphes, Sarkisian, Besen, \& Kidahashi, 2016; Posthuma \& Guerrero, 2013). Participants in this study described feeling not only pushed out of their positions due to perceptions that they were too old, but also self-imposed pressures to retire before they passed a self-imposed expiry date. Ageist assumptions about what it means to be productive can place constraints on the goal of extending working lives. These findings show that commitment to a work environment that thrives on competition, youth, and productivity above all else can have repercussions for individuals who embark on a retirement that is defined as no longer engaging in paid work.

In many ways, participants in this study had not led what we might consider typical lives: their ambition, career achievements, and income were all above average. Even in their relations to family, it was clear that many participants had spent extraordinary amounts of time focusing on their careers and, in some cases, had not abided by the normative expectations for marriage. Yet they held surprisingly conventional understandings of retirement. When it was time to retire, they either saw the writing on the wall or they were forced out because others saw it as their time to move on. Despite the fact that there are multiple overlapping criteria for identifying a person as being "retired" (Ekerdt, 2010), examining retirement transitions continues to be a pivotal point of research focus (Cahill, Giandrea, \& Quinn, 2006; Moen, Kojola, \& Schaefers, 2017; Silver, 2018; Warner, Hayward, \& Hardy, 2010). Participants' expectations for their retirement were consistent with the phenomena of bridge employment (Beehr \& Bennett, 2015; Dingemans \& Henkens, 2014; Kim \& Feldman, 2000) and encore careers (Moen, 2016; Lawrence-Lightfoot, 2009). Their experiences also support research demonstrating that financial insecurity is not a primary driver of post-retirement employment (Cahill, Giandrea, \& Quinn, 2016), and findings from this study highlight the value of creating employment opportunities that recognize the contributions mature workers bring to organizations (Drentea, 2002).

Frameworks such as the "third age" depict retirement as a time after the adult career stage when individuals 
can participate more fully in leisure activities and create a lifestyle that is not career-dominated and also not isolated from the rest of society (Gilleard \& Higgs, 2002; Laslett, 1989). In contrast to prior literature, participants in this study did not emphasize their personal satisfaction with leisure activities (Andel, Finkel, \& Pedersen, 2016), volunteer work (Moen \& Flood, 2013), and engaging with family (Szinovacz, DeViney, \& Davey, 2001) and grandchildren (Baker \& Silverstein, 2008). Unlike many retirees who face financial strain, struggle with health problems, and/or must attend to caregiving obligations, these participants struggled when they arrived at a socially imposed expiration date because their work had been an important (even paramount) source of personal fulfillment. Being retired was portrayed as a time to revisit or redefine one's core identity (Katz \& Laliberte-Rudman, 2004) and as an opportunity for individuals to alter their roles to meet their contextual needs (Ekerdt, Hackney, Kosloski, \& DeViney, 2001). Participants lingered in what Hershenson (2016) has termed "involvement status", wherein the influence of their pre-retirement experiences continued to play a pivotal role in shaping their perceptions of daily experiences in retirement. For participants in this study, the third age was a time still dominated by career interests as their core identities were so intertwined with what they had done professionally.

The women in this study began their careers at a time when fewer women participated in the paid workforce. Currently, women comprise just over four per cent of the CEOs in Fortune 500 or Fortune 1000 companies (Catalyst, 2013). In part, due to their uniqueness, there is very little research on the experiences of women CEOs (Martin, Nishikawa \& Williams, 2009), and much of this research has focused on gender-based obstacles to career advancement (Elmuti et al., 2003) or the demographic characteristics of women CEOs (Muller-Kahle \& Schiehll, 2013). Only seven women participated in this study. This relatively small sample of women may reflect the smaller number of women in CEO positions. It is noteworthy that the findings from this study reflect the unique attributes of these participants, which may differ from those of women who also held the position of CEO but did not participate in this study.

As women have begun to assume more leadership positions in the paid workforce, there has been growing interest in studying gender differences in leadership style, work-related negotiations, and management of job-related stress (Burke \& Collins, 2001; Gardiner \& Tiggemann, 1999; Kugler, Reif, Kaschner, \& Brodbeck, 2017) with evidence pointing to a number of ways stereotypes can impede women's advancement (Burgess \& Borgida, 1999; Heilman, 2012). Across different cultures, gender stereotypes that link men with greater agency, leadership skill, and productivity or that link women with dependence, domestic roles, or family responsibilities have persisted over time (Burns, 1978; Heilman \& Eagly, 2008; Williams \& Best, 1990). And although research suggests that marital histories and childrearing can be important factors when examining women's retirement experiences (Damman, Henkens, \& Kalmijn, 2015; Silver, 2010, 2016), the women in this study did not emphasize their spouses, partners, children, or family in relation to their perceptions about work, aging, and retirement. Perhaps these women had acculturated to a work environment that discouraged familial interests or obligations and consistently prioritized work.

This study only begins to scratch the surface of gender differences in the experiences of CEOs. The women in this study discussed a dedication to their work that was seemingly parallel to the descriptions shared by the men. In spite of having to overcome the obstacles associated with being underrepresented in the higher ranks, each of the women noted the contributions her work had made to the health of the communities she worked in and the strong linkages between her work and sense of personal identity in ways that were similar to descriptions shared by the men. Findings from this study contribute to a growing recognition that although women's work experiences are heterogeneous and their historical, social, and cultural orientations to work can differ from men's, a woman's deep commitment to her work is not inherently different from that of a man's.

In the quietude of their retirement, participants shared a sense that something meaningful disappeared from their lives when they stopped working. Though distinct in many ways from the characters in Milan Kundera's The Unbearable Lightness of Being (1984), participants in this study were left to face the burden of freedom. Yet, instead of feeling unburdened by work obligations, participants associated an unbearable sense of being socially insignificant with retirement. It can seem aberrant to feel sympathetic for the wealthy and elite executive who has retired too soon and whose strong social networks and determination make it likely that they will quickly re-enter the paid workforce. Prior research suggests that income is a significant predictor of adjustment to retirement (Arber, Fenn, \& Meadows, 2014; MacLean, 1983), and large financial packages for CEOs upon retirement are quite common (Yermack, 2006). However, their plight reflects a sentiment that may be shared among others in a generation stuck between contradictory notions of retirement (Benz, Sendensky, Thompson, \& Agiesta, 2013; McDonald, 2013; Pruchno, 2012). 


\section{Strengths, Limitations, and Suggestions for Future Research}

This study is a novel examination of perceptions about retirement among CEOs that contributes to theoretical work on productive aging while illustrating how commitment to work crosses gender lines and how ageist assumptions about productivity can drive workers to retire early. Nonetheless, there are some limitations to consider. First, it is important to point out that although several participants were willing to disclose personal information such as marital affairs and/or terminations that were publicly presented as retirements, the degree to which participants could reflect on their personal experiences with retiring from the careers that had been vital to their sense of self was limited by the types of questions I asked during our interviews. Another important limitation is that although this study is innovative for its inclusion of retired women CEOs, future research should continue to examine the experiences of women who retire from the position of CEO and other leadership positions.

In addition, by restricting the eligibility criteria to include only participants who were fluent in English, this study excluded the perspectives of individuals who do not speak English and thus imposed a limitation on the range of experiences that could be shared. Future research should consider accommodating participants with fluency in languages other than English. Another factor to consider is that the men and women in this study enjoyed relatively good health. Over time, as they encounter health challenges, their perceptions about work, aging, and retirement could change (Hessel, 2016; Majeed, Forder, Mishra, Kendig, \& Byles, 2016). Subsequent studies, therefore, should follow retired CEOs over time to examine how post-retirement experiences, such as declining health, influence perceptions about retirement and how they differ for men and women. Finally, interviews with participants' spouses, partners, and family members would provide more diverse insights and a deeper understanding of CEOs' relationship between work, aging, and retirement.

\section{Conclusion}

In this study, I explored the retirement experiences of a set of individuals whose careers demanded that they consistently demonstrate their productivity and persistently prioritize their work over other aspects of their life. The health care CEOs who participated in this study held trailblazing and ambitious careers that sharply contrasted with the pressures they faced to yield their reins of power despite yearning to remain engaged and grounded through work. When it was time for them to retire, participants either saw the writing on the wall or were forced out of their positions because of ageist perceptions that their workforce contributions were no longer vital to the organizations they led. Findings illustrate the value of applying a life course perspective to examining retirement and also show that high career achievement and wealth do not diminish one's desire to remain connected, to contribute, or to obtain a sense of fulfillment from paid work. Although retirement is often depicted as a time to enjoy the fruits of one's labours, participants demonstrated how preconceptions about productivity contrast with ideations of a leisure-filled retirement in ways that can foreshorten workforce contributions.

\section{References}

Andel, R., Finkel, D., \& Pedersen, N. L. (2016). Effects of preretirement work complexity and postretirement leisure activity on cognitive aging. The Journals of Gerontology: Series B, 71(5), 849-856. doi:10.1093/geronb/gbv026

Arber, S., Fenn, K., \& Meadows, R. (2014). Subjective financial well-being, income and health inequalities in mid and later life in Britain. Social Science $\mathcal{E}$ Medicine, 100, 12-20. doi:10.1016/j.socscimed.2013.10.016

Baker, L. A., \& Silverstein, M. (2008). Preventive health behaviors among grandmothers raising grandchildren. The Journals of Gerontology: Series B, 63(5), S304-S311. doi:10.1093/geronb/63.5.s304

Baltes, M. M., \& Carstensen, L. L. (1996). The process of successful ageing. Ageing $\mathcal{E}$ Society, 16(4), 397-422.

Barnes, H., \& Parry, J. (2004). Renegotiating identity and relationships: Men and women's adjustments to retirement. Ageing \& Society, 24(2), 213-233. doi:10.1017/ S0144686X0300148X

Bass, S. A., \& Caro, F. G. (2001). Productive aging: A conceptual framework. In N. Morrow-Howell, J. Hinterlong, \& M. Sherraden (Eds.), Productive aging: Concepts and challenges (pp. 37-78). Baltimore, MD: Johns Hopkins University Press.

Bass, S. A., Caro, F.G., \& Chen, Y.P. (Eds.). (1993). Achieving a productive aging society. Westport, CT: Auburn House.

Bayl-Smith, P. H., \& Griffin, B. (2014). Age discrimination in the workplace: Identifying as a late-career worker and its relationship with engagement and intended retirement age. Journal of Applied Social Psychology, 44(9), 588-599. doi:10.1111/jasp.12251

Beehr, T. A., \& Bennett, M. M. (2015). Working after retirement: Features of bridge employment and research directions. Work, Aging and Retirement, 1(1), 112-128. doi:10.1093/workar/wau007

Benz, J., Sedensky, M., Thompson, T., \& Agiesta, J. (2013). Working longer: Older Americans' attitudes on work and retirement. Chicago, IL: Associated Press-NORC Center for Public Affairs Research. 
Bülow, M. H., \& Söderqvist, T. (2014). Successful ageing: A historical overview and critical analysis of a successful concept. Journal of Aging Studies, 31, 139-149.

Burgess, D., \& Borgida, E. (1999). Who women are, who women should be: Descriptive and prescriptive gender stereotyping in sex discrimination. Psychology, Public Policy, and Law, 5(3), 665.

Burke, S., \& Collins, K. M. (2001). Gender differences in leadership styles and management skills. Women in Management Review, 16(5), 244-257.

Burns, J. M. (1978). Leadership. New York, NY: Harper and Row.

Butler, R. N., \& Gleason, H. P. (1985). Productive aging. New York, NY: Springer.

Cahill, K. E., Giandrea, M. D., \& Quinn, J. F. (2006). Are traditional retirements a thing of the past? New evidence on retirement patterns and bridge jobs. Business Perspectives, 18(2), 26-37.

Cahill, K. E., Giandrea, M. D., \& Quinn, J. F. (2016). To what extent is gradual retirement a product of financial necessity? Work, Aging, and Retirement, 3(1), 25-54. doi:10.1093/workar/waw027

Carney, G. M., \& Gray, M. (2015). Unmasking the 'elderly mystique': Why it is time to make the personal political in ageing research. Journal of Aging Studies, 35, 123-134. doi:10.1016/j.jaging.2015.08.007

Carrière, Y., \& Galarneau, D. (2012). How many years to retirement? Ottawa, ON: Statistics Canada.

Catalyst. (2013). Women CEOs of the S\&P 500. Retrieved from http:/ / catalyst.org/knowledge/women-ceos-fortune1000

Chassin, M. R., \& Loeb, J. M. (2013). High-reliability health care: Getting there from here. Milbank Quarterly, 91(3), 459-490. doi:10.1111/1468-0009.12023

Cohn, D.'V, and Taylor, P. (2010). Baby boomers approach 65 - glumly. Washington, D.C.: Pew Research Center. Retrieved from http://www.pewsocialtrends.org/ 2010/12/20/baby-boomers-approach-65-glumly/

Damman, M., Henkens, K., \& Kalmijn, M. (2015). Women's retirement intentions and behavior: The role of childbearing and marital histories. European Journal of Population, 31(4), 339-363. doi:10.1007/s10680-014-9335-8

de Medeiros, K. (2013). Narrative gerontology in research and practice. New York, NY: Springer.

Dillaway, H. E., \& Byrnes, M. (2009). Reconsidering successful aging: A call for renewed and expanded academic critiques and conceptualizations. Journal of Applied Gerontology, 28(6), 702-722. doi:10.1177/0733464809333882

Dingemans, E., \& Henkens, K. (2014). Involuntary retirement, bridge employment, and satisfaction with life: A longitudinal investigation. Journal of Organizational Behavior, 35(4), 575-591. doi:10.1002/job.1914
Drentea, P. (2002). Retirement and mental health. Journal of Aging and Health, 14(2), 167-194. doi:10.1177/ 089826430201400201

Ekerdt, D. J. (1986). The busy ethic: Moral continuity between work and retirement. The Gerontologist, 26(3), 239-244. doi:10.1093/geront/26.3.239

Ekerdt, D. J. (2004). Born to retire: The foreshortened life course. The Gerontologist, 44(1), 3-9.

Ekerdt, D. J. (2010). Frontiers of research on work and retirement. The Journals of Gerontology: Series B, 65B(1), 69-80. doi:10.1093/geronb/gbp109

Ekerdt, D. J., \& DeViney, S. (1990). On defining persons as retired. Journal of Aging Studies, 4(3), 211-229.

Ekerdt, D. J., Hackney, J., Kosloski, K., \& DeViney, S. (2001). Eddies in the stream: The prevalence of uncertain plans for retirement. The Journals of Gerontology: Series B, 56(3), S162-S170. doi:10.1093/geronb/56.3.s162

Elder, G. H., Jr. (1994). Time, human agency, and social change: Perspectives on the life course. Social Psychology Quarterly, 57(1), 4. doi:10.2307/2786971

Elmuti, D., Lehman, J., Harmon, B., Lu, X., Pape, A., Zhang, R., \& Zimmerle, T. (2003). Inequality between genders in the executive suite in corporate America: Moral and ethical issues. Equal Opportunities International, 22(2), 40-58. doi:10.1108/02610150310787351

Foster, L., \& Walker, A. (2014). Active and successful aging: A European policy perspective. The Gerontologist, 55(1), 83-90. doi:10.1093/geront/gnu028

Gardiner, M., \& Tiggemann, M. (1999). Gender differences in leadership style, job stress and mental health in male - and female - dominated industries. Journal of Occupational and Organizational Psychology, 72(3), 301-315. doi:10.1348/096317999166699

Giele, J. Z., \& Elder, Jr., G.H. (1998). Methods of life course research: Qualitative and quantitative approaches. Thousand Oaks, CA: Sage.

Gilleard, C., \& Higgs, P. (2002). The third age: Class, cohort or generation? Ageing $\mathcal{E}$ Society, 22(03), 369-382. doi:10.1017/S0144686X0200870X

Gonzales, E., Matz-Costa, C., \& Morrow-Howell, N. (2015). Increasing opportunities for the productive engagement of older adults: A response to population aging. The Gerontologist, 55(2), 252-261. doi:10.1093/ geront/gnu176

Hardy, M. (2011). Rethinking retirement. In R. Settersten \& J. Angel (Eds.), Handbook of sociology of aging (pp. 213-227). New York, NY: Springer.

Heilman, M. E. (2012). Gender stereotypes and workplace bias. Research in Organizational Behavior, 32, 113-135.

Heilman, M. E., \& Eagly, A. H. (2008). Gender stereotypes are alive, well, and busy producing workplace discrimination. 
Industrial and Organizational Psychology, 1(4), 393-398. doi:10.1111/j.1754-9434.2008.00072.x

Hershenson, D. B. (2016). Reconceptualizing retirement: A status-based approach. Journal of Aging Studies, 38, 1-5. doi:10.1016/j.jaging.2016.04.001

Hessel, P. (2016). Does retirement (really) lead to worse health among European men and women across all educational levels? Social Science \& Medicine, 151, 19-26.

Hicks, S. A., \& Siedlecki, K. L. (2017). Leisure activity engagement and positive affect partially mediate the relationship between positive views on aging and physical health. The Journals of Gerontology: Series B, 72(2), 259-267.

Higgs, P., \& Gilleard, C. (2006). Departing the margins: Social class and later life in a second modernity. Journal of Sociology, 42(3), 219-241. doi:10.1177/1440783306066724

Holstein, M. (1993). Productive aging: A feminist critique. Journal of Aging $\mathcal{E}$ Social Policy, 4(3-4), 17-34.

Katz, S. (2000). Busy bodies: Activity, aging, and the management of everyday life. Journal of Aging Studies, 14(2), 135-152. doi:10.1016/S0890-4065(00)80008-0

Katz, S. (2001). Growing older without aging? Positive aging, anti-ageism, and anti-aging. Generations, 25(4), 27-32.

Katz, S. (2005). Cultural aging: Life course, lifestyle, and senior worlds. Toronto, ON: University of Toronto Press.

Katz, S., \& Calasanti, T. (2014). Critical perspectives on successful aging: Does it "appeal more than it illuminates"? The Gerontologist, 55(1), 26-33. doi:10.1093/geront/gnu027

Katz, S., \& Laliberte-Rudman, D. (2004). Exemplars of retirement: Identity and agency between lifestyle and social movement. In E. Tulle (Ed.), Old age and agency (pp. 45-65). Hauppauge, NY: Nova Science Press.

Kenyon, G., Bohlmeijer, E., \& Randall, W. L. (Eds.). (2010). Storying later life: Issues, investigations, and interventions in narrative gerontology. New York, NY: Oxford University Press.

Kenyon, G. M., Clark, P. G., \& de Vries, B. (Eds.). (2001). Narrative gerontology: Theory, research, and practice. New York, NY: Springer.

Kim, S., \& Feldman, D. C. (2000). Working in retirement: The antecedents of bridge employment and its consequences for quality of life in retirement. Academy of Management Journal, 43(6), 1195-1210. doi:10.2307/1556345

Klevens, R. M., Edwards, J. R., Richards, Jr., C. L., Horan, T. C., Gaynes, R. P., Pollock, D. A., \& Cardo, D. M. (2007). Estimating health care-associated infections and deaths in US hospitals, 2002. Public Health Reports, 122(2), 160-166.

Kugler, K. G., Reif, J. A., Kaschner, T., \& Brodbeck, F. C. (2017). Gender differences in the initiation of negotiations: A meta-analysis. Psychological Bulletin, 144(2), 198-222.
Kundera, M. (1984). The unbearable lightness of being. London, ENG: Faber \& Faber.

Laslett, P. (1989). A fresh map of life: The emergence of the third age. London, ENG: Weidenfeld and Nicolson.

Lawrence-Lightfoot, S. (2009). The third chapter: Passion, risk, and adventure in the 25 years after 50. New York, NY: Sarah Crichton Books.

Lincoln, Y. S., \& Guba, E. G. (1985). Naturalistic inquiry. Beverly Hills, CA: Sage.

MacLean, M. J. (1983). Differences between adjustment to and enjoyment of retirement. Canadian Journal on Aging/La Revue canadienne du vieillissement, 2(1), 3-8. doi:10.1017/ S0714980800015592

Maestas, N. (2010). Back to work: Expectations and realizations of work after retirement. The Journal of Human Resources, 45(3), 718-748. doi:10.1353/jhr. 2010.0011

Majeed, T., Forder, P. M., Mishra, G., Kendig, H., \& Byles, J. E. (2016). Exploring workforce participation patterns and chronic diseases among middle-aged Australian men and women over the life course. Journal of Aging and Health, 29(2), 343-361. doi:10.1177/ 0898264316635586

Marshall, B. L., \& Katz, S. (2002). Forever functional: Sexual fitness and the ageing male body. Body E Society, 8(4), 43-70. doi:10.1177/1357034X02008004003

Marshall, V. W., \& Mueller, M. M. (2003). Theoretical roots of the life-course perspective. In W. R. Heins \& V. W. Marshall (Eds.), Social dynamics of the life course: Transitions, institutions, and interrelations (pp. 3-32). New York, NY: Aldine de Gruyter.

Martin, A., Nishikawa, T., \& Williams, M. (2009). CEO gender: Effects on valuation and risk. Quarterly Journal of Finance and Accounting, 48(3), 23-40.

Martinson, M., \& Halpern, J. (2011). Ethical implications of the promotion of elder volunteerism: A critical perspective. Journal of Aging Studies, 25(4), 427-435. doi:10.1016/j.jaging.2011.04.003

McDonald, L. (2013). The evolution of retirement as systematic ageism. Dordrecht, NLD: Springer Science+Business Media.

McDonald, L., \& Donahue, P. (2011). Retirement lost? Canadian Journal on Aging/La revue canadienne du vieillissement, 30(03), 401-422. doi:10.1017/S0714980811000298

McNamara, T. K., Pitt-Catsouphes, M., Sarkisian, N., Besen, E., \& Kidahashi, M. (2016). Age bias in the workplace: Cultural stereotypes and in-group favoritism. The International Journal of Aging and Human Development, 83(2), 156-183. doi:10.1177/0091415016648708

Miles, M. B., \& Huberman, A. M. (1994). Qualitative data analysis: An expanded sourcebook. Thousand Oaks, CA: Sage. 
Moen, P. (2016). Encore adulthood: Boomers on the edge of risk, renewal, and purpose. New York, NY: Oxford University Press.

Moen, P., \& Flood, S. (2013). Limited engagements? Women's and men's work/volunteer time in the encore life course stage. Social Problems, 60(2), 206-233. doi:10.1525/ sp.2013.60.2.206

Moen, P., Kojola, E., \& Schaefers, K. (2017). Organizational change around an older workforce. The Gerontologist, 57(5), 847-856. doi:10.1093/geront/gnw048

Moen, P., \& Roehling, P.V. (2005). The career mystique: Cracks in the American dream. Boulder, CO: Rowman \& Littlefield.

Morrow-Howell, N., Hinterlong, J., \& Sherraden, M. (Eds.). (2001). Productive aging: Concepts and challenges. Baltimore, MD: John Hopkins University Press.

Morrow-Howell, N., \& Wang, Y. (2013). Productive engagement of older adults: Elements of a cross-cultural research agenda. Ageing International, 38(2), 159-170. doi:10.1007/ s12126-012-9165-0

Muller-Kahle, M. I., \& Schiehll, E. (2013). Gaining the ultimate power edge: Women in the dual role of CEO and chair. The Leadership Quarterly, 24(5), 666-679. doi:10.1016/ j.leaqua.2013.05.001

Obodaru, O. (2012). The self not taken: How alternative selves develop and how they influence our professional lives. Academy of Management Review, 37(1), 34-57. doi:10.5465/amr.2009.0358

O'Reilly, P., \& Caro, F. G. (1995). Productive aging: An overview of the literature. Journal of Aging $\mathcal{E}$ Social Policy, 6(3), 39-71. doi:10.1300/J031v06n03_05

Osborne, J. W. (2009). Commentary on retirement, identity, and Erikson's developmental stage model. Canadian Journal on Aging/La Revue canadienne du vieillissement, 28(4), 295-301. doi:10.1017/S0714980809990237

Patton, M. Q. (1990) Qualitative evaluation and research methods (2nd ed.). Thousand Oaks, CA: Sage.

Phoenix, C., \& Smith, B. (2011). Telling a (Good?) counterstory of aging: Natural bodybuilding meets the narrative of decline. The Journals of Gerontology: Series B, 66B(5), 628-639. doi:10.1093/geronb/gbr077

Posthuma, R. A., \& Guerrero, L. (2013). Age stereotypes in the workplace: Multidimensionality, cross-cultural applications, and directions for future research. In J. Field, R. J. Burke, \& C. L. Cooper (Eds.), The Sage handbook of aging, work and society (pp. 250-265). Thousand Oaks, CA: Sage.

Powell, J. L., \& Taylor, P. (2016). Rethinking risk and aging: Extending working lives. Social Policy and Society, 15(4), 637-645.

Price, C. A. (2000). Women and retirement: Relinquishing professional identity. Journal of Aging Studies, 14(1), 81-101. doi:10.1016/S0890-4065(00)80017-1
Price, C. A. (2003). Professional women's retirement adjustment: The experience of reestablishing order. Journal of Aging Studies, 17(3), 341-355.

Price, C.P., \& Nesteruk, O. (2010). Creating retirement paths: Examples from the lives of women. Journal of Women $\mathcal{E}$ Aging, 22(2), 136-149. doi:10.1080/08952841003719240

Pruchno, R. (2012). Not your mother's old age: Baby boomers at age 65. The Gerontologist, 52(2), 149-152. doi:10.1093/ geront/gns038

Sargeant, M. (2016). Age discrimination in employment: Ageism in employment and service provision. Hampshire, ENG: Gower.

Savishinsky, J. (1995). The unbearable lightness of retirement: Ritual and support in a modern life passage. Research on Aging, 17(3), 243-259. doi:10.1177/0164027595173001

Sass, S. (2006). The development of employer retirement income plans: From the nineteenth century to 1980. In G. L. Clark, A. H. Munnell, and J. M. Orszag (Eds.), The Oxford handbook of pensions and retirement income (pp. 76-97). Oxford, ENG: Oxford University Press.

Silver, M. P. (2010). Women's retirement and self-assessed well-being: An analysis of three measures of well-being among recent and long-term retirees relative to homemakers. Women \& Health, 50(1), 1-19. doi:10.1080/ 03630241003601111

Silver, M. P. (2016). An inquiry into self-identification with retirement. Journal of Women \& Aging, 28(6), 477-488. doi:10.1080/08952841.2015.1018068

Silver, M. P. (2018). Retirement and Its Discontents: Why we won't stop working, even if we can. New York, NY: Columbia University Press.

Sonnenfeld, J. A. (1991). The hero's farewell: What happens when CEOs retire. New York, NY: Oxford University Press.

Statistics Canada (2017a). 2016 census topic: Age and sex. Ottawa, ON: Author. Retrieved from http:/ /www12. statcan.gc.ca/census-recensement/2016/rt-td/as-eng.cfm

Statistics Canada (2017b). Life expectancy. Ottawa, ON: Author. Retrieved from https://www.statcan.gc.ca/ eng/help/bb/info/life

Swayne, L. E., Duncan, W. J., \& Ginter, P. M. (2012). Strategic management of health care organizations. West Sussex, ENG: John Wiley \& Sons.

Szinovacz, M.E. (2003). Contexts and pathways: Retirement as institution, process, and experience. In G. A. Adams \& T. A. Beehr (Eds.), Retirement: Reasons, processes, and results (pp. 6-52). New York, NY: Springer.

Szinovacz, M. E., DeViney, S., \& Davey, A. (2001). Influences of family obligations and relationships on retirement: Variations by gender, race, and marital status. The Journals of Gerontology: Series B, 56(1), S20-S27. doi:10.1093/ geronb/56.1.s20 
Vickerstaff, S. (2010). Older workers: The 'unavoidable obligation' of extending our working lives? Sociology Compass, 4(10), 869-879.

Vickerstaff, S., \& Cox, J. (2005). Retirement and risk: The individualisation of retirement experiences. The Sociological Review, 53(1), 77-95.

Warner, D. F., Hayward, M. D., \& Hardy, M. A. (2010). The retirement life course in America at the dawn of the 21st century. Population Research and Policy Review, 29(6), 893-919. doi:10.1007/s11113-009-9173-2
Williams, J. E., \& Best, D. L. (1990). Measuring sex stereotypes: A multinational study (revised edition). Beverly Hills, CA: Sage.

World Bank Group. (2016). Life expectancy at birth, male (years). World Bank Data. Last modified 2016. Washington, D.C.: Author. http:/ / data.worldbank.org/indicator/SP.DYN. LE00.MA.IN

Yermack, D. (2006). Golden handshakes: Separation pay for retired and dismissed CEOs. Journal of Accounting and Economics, 41(3), 237-256. 